\title{
Pyrococcus glycovorans sp. nov., a hyperthermophilic archaeon isolated from the East Pacific Rise
}

\author{
Georges Barbier, ${ }^{1}$ Anne Godfroy, ${ }^{1}$ Jean-Roch Meunier, ${ }^{2} \dagger$ Joël Quérellou, ${ }^{1}$ \\ Marie-Anne Cambon, ${ }^{1}$ Françoise Lesongeur, ${ }^{1}$ Patrick A. D. Grimont ${ }^{2}$ \\ and Gérard Raguénès ${ }^{1}$
}

Author for correspondence: Georges Barbier. Tel: +332982245 21. Fax: +33298224545.

e-mail: gbarbier@ifremer.fr

\footnotetext{
1 Laboratoire de Caractérisation des Microorganismes Marins, IFREMER, Centre de Brest, BP 70, 29280 Plouzané France

2 Unité des Entérobactéries, Institut Pasteur, 75724 Paris cedex 15, France
}

\begin{abstract}
A hyperthermophilic archaeon, strain AL585', was isolated from a deep-sea hydrothermal vent located on the East Pacific Rise at latitude $13^{\circ} \mathrm{N}$ and a depth of $2650 \mathrm{~m}$. The isolate was a strictly anaerobic coccus with a mean cell diameter of $1 \mu \mathrm{m}$. The optimum temperature, $\mathrm{pH}$ and concentration of sea salt for growth were $95{ }^{\circ} \mathrm{C}, 7.5$ and $30 \mathrm{~g} \mathrm{I}^{-1}$. Under these conditions, the doubling time and cell yield were $0.5 \mathrm{~h}$ and $5 \times 10^{8}$ cells $\mathrm{ml}^{-1}$. Strain $\mathrm{AL585}^{\top}$ grew preferentially in media containing complex proteinaceous carbon sources, glucose and elemental sulfur. The $G+C$ content of the DNA was $47 \mathrm{~mol} \%$. Sequencing of the $16 \mathrm{~S}$ rDNA gene showed that strain AL585' belonged to the genus Pyrococcus and was probably a new species. This was confirmed by total DNA hybridization. Consequently, this strain is described as a new species, Pyrococcus glycovorans sp. nov.
\end{abstract}

Keywords: archaea, Pyrococcus, hyperthermophile, deep-sea, hydrothermal vent

\section{INTRODUCTION}

From the beginning of the last decade, the scientific community has been increasingly interested in hyperthermophiles, i.e. strains with temperature optima for growth above $80^{\circ} \mathrm{C}$ (Brock, 1992). Such organisms are attractive objects for basic research into the molecular basis of thermophily, thermostability and the origin of life as well as for applied research (Blöchl et al., 1995). At present, the industrial applications of hyperthermophiles are related to their ability to produce thermostable enzymes (Leuschner \& Antranikian, 1995). In this regard, the Thermococcales is the most frequently studied archaeal order and Pyrococcus is the most frequently studied genus within the hyperthermophiles (Leuschner \& Antranikian, 1995). At present, the genus Pyrococcus contains only four species: Pyrococcus furiosus (Fiala \& Stetter, 1986), Pyrococcus woesei (Zillig et al., 1987), 'Pyrococcus abyssi' (Erauso et al., 1993) and 'Pyrococcus horikoshii' (Gonzalez et al., 1998). P. furiosus and $P$.

\footnotetext{
†Present address: L'Oréal, Recherche avancée, DCSP - Phototoxicité, 1 Avenue Eugène Schueller, 93600 Aulnay-sous-Bois, France.

The GenBank/EMBL accession number for the 16S rDNA sequence of strain $\mathrm{AL}^{2} 85^{\top}$ is $\mathrm{Z70247.}$
}

woesei are subjective synonyms (Erauso et al., 1993) and their 16S rDNA and DNA polymerases sequences are identical (J. Quérellou, unpublished data). Both were isolated from samples collected from marine solfataras of Vulcano island, Italy. ' $P$. abyssi' and ' $P$. horikoshii' were isolated from deep-sea vents of the North Fiji Basin (Erauso et al., 1993) and Okinawa Trough (Gonzalez et al., 1998), respectively. Pyrococcus species are coccoid marine archaea, strictly anaerobic, heterotrophic and sulfur-reducing with optimal temperatures for growth in the range 95$100^{\circ} \mathrm{C}$. Substrates for growth include complex organic substrates such as yeast extract, peptone, tryptone, meat extract and peptides (Fiala \& Stetter, 1986). $P$. furiosus can also grow on starch, maltose (Fiala \& Stetter, 1986; Raven \& Sharp, 1997), glycogen, pullulan (Brown et al., 1990), pyruvate (Schäfer \& Schönheit, 1991) and cellobiose (Kengen et al., 1993). $P$. woese $i$ can grow on glycogen, starch and gellan gum (Zillig et al., 1987; Koch et al., 1991;Rüdiger et al., 1992, 1995). 'P. abyssi' and 'P. horikoshii' are unable to grow on carbohydrates (Erauso et al., 1993; Gonzalez et al., 1998). This report describes a novel hyperthermophilic species of the genus Pyrococcus isolated from samples collected on the East Pacific Rise. 


\section{METHODS}

Reference strains. $P$. furiosus DSM $3638^{\mathrm{T}}$ and Thermotoga maritima DSM $3109^{\mathrm{T}}$ were obtained from the Deutsche Sammlung von Mikroorganismen und Zellkulturen, Braunschweig-Stöckheim, Germany. ' $P$. abyssi' was provided by Gaël Erauso (Centre National de la Recherche Scientifique, Station Biologique, Roscoff, France).

Culture conditions. BHI-S medium contained $\left(1^{-1}\right): 9 \mathrm{~g}$ brain heart infusion (Difco), $23 \mathrm{~g} \mathrm{NaCl}$ (instead of sea salt, to prevent formation of mineral precipitate), $6.05 \mathrm{~g}$ PIPES buffer (Sigma), $10 \mathrm{~g}$ sulfur (Prolabo) and $1 \mathrm{mg}$ resazurin (Sigma). 2216-S medium (Belkin \& Jannasch, 1985) contained $\left(1^{-1}\right): 2$ g peptone (Difco), 0.5 g yeast extract (Difco), $30 \mathrm{~g}$ sea salt (Sigma, ref. S-9883), 6.05 g PIPES buffer, $10 \mathrm{~g}$ sulfur and $1 \mathrm{mg}$ resazurin. 20AA-S medium contained $\left(1^{-1}\right)$ : $30 \mathrm{~g}$ sea salt, $6.05 \mathrm{~g}$ PIPES buffer, $10 \mathrm{~g}$ sulfur, $1 \mathrm{mg}$ resazurin, $10 \mathrm{ml}$ of a mineral solution (Balch et al., 1979), $10 \mathrm{ml}$ of a vitamin solution (Balch et al., 1979) and each of the 20 classical amino acids at a concentration of $2 \mathrm{mM}$. A stock solution of the 20 amino acids each at a concentration of $2 \mathrm{mM}$ was sterilized separately by $0.22 \mu \mathrm{m}$ filtration (Nalgene). The $\mathrm{pH}$ was adjusted with $5 \mathrm{M} \mathrm{NaOH}$ and $5 \mathrm{M}$ $\mathrm{HCl}$ (measured at room temperature and atmosphere). The media were steam-sterilized at $100^{\circ} \mathrm{C}$ (in order to avoid melting of sulfur and solidification in blocks at higher temperatures) for $30 \mathrm{~min}$ on two successive days, transferred into an anaerobic chamber (La Calhène, France) containing a gas mixture of $\mathrm{N}_{2}, \mathrm{H}_{2}$ and $\mathrm{CO}_{2}(90: 5: 5)$, reduced by addition of sodium sulfide (Sigma) at a final concentration of $0.5 \mathrm{~g} \mathrm{l}^{-1}$ and then distributed into Hungate tubes or into $50 \mathrm{ml}$ serum vials that were closed with a butyl rubber stopper and an aluminium cap. Unless indicated otherwise, cultures were grown on BHI-S or 2216-S medium at $\mathrm{pH} 7 \cdot 5$ (measured at room temperature) and always incubated at atmospheric pressure $(100 \mathrm{kPa})$ under the anaerobic gas mixture mentioned above at $95^{\circ} \mathrm{C}$. Cultures were inoculated with previous cultures at $5 \%(\mathrm{v} / \mathrm{v})$.

Enrichment cultures and purification. After collection, samples were stored on board for 2-3 weeks at room temperature and then in the laboratory at $4{ }^{\circ} \mathrm{C}$ in serum vials filled with sterile sea water (sea salt, $30 \mathrm{~g} \mathrm{l}^{-1}$ ) under anaerobic conditions $\left(\mathrm{N}_{2}\right.$ gas phase and $0.5 \mathrm{~g}$ sodium sulfide $\left.\mathrm{l}^{-1}\right)$. Samples from the MVT'90 cruise were ground and used for inoculation $(10 \% \mathrm{v} / \mathrm{v})$ of $2216-\mathrm{S}$ and BHI-S media prepared at different $\mathrm{pHs}(3 \cdot 5,5 \cdot 5$ and $7 \cdot 5)$ and incubated at $60,80,95$, 100 and $110^{\circ} \mathrm{C}$. Positive cultures were identified by the appearance of turbidity and the presence of cells as revealed by microscopic observation. Cultures were then purified by streaking enrichment samples onto the same media solidified with Gelrite (Scott Laboratories) as gelling agent and incubated at $95^{\circ} \mathrm{C}$ in glass Petri dishes set down in jars prepared under the gas mixture (Godfroy et al., 1997). A collection of 125 thermophilic strains was obtained from those samples (Raguénès et al., 1995).

Storage. Purified isolates were grown in BHI-S liquid culture media. Cultures in exponential growth phase were stored anaerobically in cryotubes (useful volume of $1.8 \mathrm{ml}$ ) for long-term storage, at $-20^{\circ} \mathrm{C}$ and $-70^{\circ} \mathrm{C}$, after addition of dimethyl sulfoxide $(5 \% \mathrm{v} / \mathrm{v})$ (Sigma) as cryoprotectant. Cultures in exponential growth phase were also stored at $4{ }^{\circ} \mathrm{C}$ and were usable for at least 1 year.

Optical microscopy and determination of cell densities. Cell number was determined with an Olympus (Japan) microscope, model BH-2, and a Thoma chamber (depth of $0.02 \mathrm{~mm}$ ). Specific coloration using the Spot Test Flagella
(Difco) was done for microscopic observation of flagella. When many non-microbial particles were observed (for instance with starch or at temperatures higher than $100^{\circ} \mathrm{C}$ ), cells were counted by epifluorescent microscopy (Hobbie et al., 1977). Samples were diluted in sterile water containing sea salt $\left(30 \mathrm{~g}^{-1}\right)$, formalin $(2.5 \%)$ and acridine orange $(0 \cdot 01 \%)$ and filtered onto black nuclepore polycarbonate membrane filters (pore size $0.2 \mu \mathrm{m}$; Costar). The acridine orange counts were confirmed by staining additional cultures with the DNA-specific stain 4',6-diamidino-2-phenylindole (Porter \& Feig, 1980).

For determination of the optimum $\mathrm{pH}$ and salinity for growth, the turbidity of cultures in 2216-S medium was also quantified with a spectrophotometer (Spectronic 301; Milton Roy). Before taking measurements, Hungate tubes were gently mixed by inversion. After $6 \mathrm{~min}$, sulfur particles had settled and $\mathrm{OD}_{600}$ were measured. Absorbance varied linearly with cell numbers from $2.5 \times 10^{7}$ to $1.5 \times 10^{8}$ cells $\mathrm{ml}^{-1}$ or $\mathrm{OD}_{600}$ of $0 \cdot 05-0 \cdot 25$. A regression through the origin gave the following formula: cells $\mathrm{ml}^{-1}=4.5 \times 10^{8} \times \mathrm{OD}_{600}$ $\left(n=7, r^{2}=0.98\right)$.

For flow-cytometric analysis, cells were fixed for $15 \mathrm{~min}$ at room temperature with $1 \%$ paraformaldehyde (final concentration). Filtered artificial sea water (Sigma, ref. S-1649) was used to dilute samples if necessary. Nucleic acid staining was achieved by addition of SYBR Green-I (Molecular Probes) at a final dilution of $10^{-4}$ of the commercial solution and $0 \cdot 1 \%$ Triton X-100. Samples were incubated for 15-30 min at room temperature in the dark. Enumeration of cells were performed with a FACSort flow cytometer (Becton Dickinson) equipped with an air-cooled laser providing $15 \mathrm{~mW}$ at $488 \mathrm{~nm}$ and with the standard filter set-up. Forward and right-angle light scatters (FSC and SSC) as well as the green fluorescence of the complex DNA-SYBR Green were collected on logarithmic signals. Samples were run at a calibrated rate of $50 \mu \mathrm{min}^{-1}$ and dilutions of the samples in filtered artificial sea water were adapted such that the event rate was below 800 cells $\mathrm{s}^{-1}$ to avoid coincidence. Data were recorded as list-mode files and processed with custom-designed software CYTOWIN (D. Vaulot, unpublished; available online at http:/ /www.sb-roscoff.fr), which discriminates cell populations by using a combination of all the parameters recorded.

Electron microscopy. For transmission electron microscopy, cells were harvested at the end of the exponential phase of growth and centrifuged. The pellet was resuspended and fixed for $1 \mathrm{~h}$ at $4{ }^{\circ} \mathrm{C}$ in $2.5 \%$ glutaraldehyde in $0 \cdot 1 \mathrm{M}$ sodium cacodylate buffer ( $\mathrm{pH} 7 \cdot 2,1100$ mosmol) and then post-fixed for $1 \mathrm{~h}$ at $4{ }^{\circ} \mathrm{C}$ in $1 \% \mathrm{OsO}_{4}$ in $0.1 \mathrm{M}$ sodium cacodylate buffer ( $\mathrm{pH} 7 \cdot 2,1100$ mosmol). After dehydration with increasing ethanol concentrations (70, 95 and $100 \%, \mathrm{v} / \mathrm{v})$, cells were embedded in EMBed 812 resin, thin-sectioned, contrasted with $7 \%(\mathrm{w} / \mathrm{v})$ uranyl acetate in methanol and a $2.5 \%(\mathrm{w} / \mathrm{v})$ aqueous solution of lead citrate and examined with a model 100CX transmission microscope (JEOL).

Determination of growth parameters. In order to determine the optimum temperature, $\mathrm{pH}$ and salinity for growth, cells were grown in Hungate tubes containing $6 \mathrm{ml} \mathrm{2216-S}$ medium. The headspace gas was $\mathrm{N}_{2} / \mathrm{H}_{2} / \mathrm{CO}_{2}(90: 5: 5)$ at $100 \mathrm{kPa}$ below and $200 \mathrm{kPa}$ above $100^{\circ} \mathrm{C}$. Temperatures were maintained with aluminium heating blocks (Barnstead) and were monitored with temperature probes placed in control tubes. $\mathrm{pH}$ and salinity effects on growth were studied at $95^{\circ} \mathrm{C}$. Optimum $\mathrm{pH}$ was determined with $2216-\mathrm{S}$ medium modified as follows: $\mathrm{pH} 2 \cdot 5,3.5$ and 4.5 , no buffer; $\mathrm{pH} 5.5$ and 6.5, MES buffer (Sigma), $1 \mathrm{~g} \mathrm{l}^{-1} ; \mathrm{pH} 7 \cdot 5$, HEPES buffer 
(Sigma), $1 \mathrm{~g} \mathrm{l}^{-\mathbf{1}}$; and $\mathrm{pH} 8 \cdot 5$ and 9.5, AMPSO buffer (Sigma), $1 \mathrm{~g} \mathrm{l}^{-1} . \mathrm{pH}$ was adjusted with $5 \mathrm{M} \mathrm{NaOH}$ and $5 \mathrm{M} \mathrm{HCl}$ (measured at room temperature and pressure). Salt requirement was determined with 2216-S medium modified with different dilutions of sea salt. Three replicates were simultaneously studied at each temperature, $\mathrm{pH}$ or salinity.

Determination of growth requirements. Utilization of different individual carbon sources for growth was tested. Individual carbon sources were added to a defined medium that contained $\left(1^{-1}\right): 30 \mathrm{~g}$ sea salt, $0 \cdot 4 \mathrm{~g}$ ammonium chloride, $6.05 \mathrm{~g}$ PIPES buffer, $10 \mathrm{ml}$ mineral solution (Balch et al., 1979), $10 \mathrm{ml}$ vitamin solution (Balch et al., 1979), $10 \mathrm{~g}$ sulfur and $1 \mathrm{mg}$ resazurin. Carbon sources were added at concentrations of $5 \mathrm{~g} \mathrm{I}^{-1}$ except for starch, chitin, cellulose and lactose, which were added at $10 \mathrm{gl}^{-1}$, and ethanol, which was added at $5 \mathrm{ml} \mathrm{l}^{-1}$. Growth on 20AA-S was also tested. Negative controls were performed with tubes without any addition of nitrogen and carbon substrate. Such tubes, prepared with $\mathrm{H}_{2} / \mathrm{CO}_{2}(80: 20)$ headspace gas mixture as sole carbon source, were used to examine the possibility of autotrophic growth. To examine growth without elemental sulfur, cells were cultured simultaneously on BHI-S and BHI (i.e. BHI-S medium without sulfur) media. For this experiment, the headspace gases on BHI medium were $\mathrm{N}_{2} / \mathrm{H}_{2} /$ $\mathrm{CO}_{2}(90: 5: 5)$ and $\mathrm{H}_{2} / \mathrm{CO}_{2}(80: 20)$ at a pressure of $100 \mathrm{kPa}$ and the reductant was titanium nitrilotriacetate (Moensch \& Zeikus, 1983) at a concentration of $200 \mu \mathrm{M}$. Growth on cystine $\left(10 \mathrm{~g} \mathrm{l}^{-1}\right)$ and on polysulfide $(10 \mathrm{mM})$ (Blumentals et al., 1990) were also investigated. For all these experiments, the $\mathrm{pH}$ was adjusted to $7 \cdot 5$ (measured at room temperature and atmosphere).

Growth rates and confidence intervals. Growth rates were determined by linear regression of semi-logarithmic plots of cell concentration against time. The doubling time $\left(t_{\mathrm{d}}\right)$ was calculated from the slope $(\mu): t_{\mathrm{d}}=\log _{10}(2) / \mu$. Confidence intervals were calculated using standard errors of the slope $\left(\mathrm{se}_{\mu}\right)$ as: $\mu \pm 2 \mathrm{se}_{\mu}$. When replicates $(n)$ were available, the mean growth rate and related standard error were calculated as: $\mu=\left(\Sigma \mu_{\mathrm{i}}\right) / n$ and $\mathrm{se}_{\mu}=\left[\Sigma\left(\mathrm{se}_{\mu \mathrm{i}}\right)^{2} / n^{2}\right]^{0.5}$.

Antibiotic sensitivity. Sensitivity to antibiotics (chloramphenicol, kanamycin, penicillin, rifampicin, streptomycin and vancomycin; all from Sigma) was tested at $80^{\circ} \mathrm{C}$ in BHI-S medium at concentrations of 50,100 and $150 \mu \mathrm{g} \mathrm{ml}^{-1}$. Thermotoga maritima was used as a bacterial control to test the efficiency of antibiotics at $80^{\circ} \mathrm{C}$. ' $P$. abyssi' (strain ST549) was used as an archaeal control to test the growth of another archaeon in the presence of antibiotics.

DNA extraction and base composition. DNA was prepared from cells harvested at the end of the exponential phase of growth. After centrifugation, the cell pellet was suspended in $5 \mathrm{ml}$ lysis buffer ( $100 \mathrm{mM}$ Tris $/ \mathrm{HCl}, 100 \mathrm{mM} \mathrm{NaCl}, 0.5 \mathrm{mM}$ EDTA; pH 8$)$ and then $1 \%(\mathrm{w} / \mathrm{v})$ Sarkosyl, $1 \%(\mathrm{w} / \mathrm{v})$ SDS and $0.4 \mathrm{mg}$ proteinase $\mathrm{K}^{-1}$ were added to achieve cell lysis. After $3 \mathrm{~h}$ incubation at $40{ }^{\circ} \mathrm{C}$, three extractions with cold phenol/chloroform/isoamyl alcohol (24:24:1) and one extraction with chloroform were performed (1:1 with lysate). Between the first and second phenol/chloroform/isoamyl alcohol extractions, DNA was treated with RNase (5 $\mathrm{gg}$ $\mathrm{ml}^{-1}$ ) for $1 \mathrm{~h}$ at $60^{\circ} \mathrm{C}$. DNA was then precipitated by addition of 2 vols ethanol at $-20^{\circ} \mathrm{C}$. The dried DNA pellet was resuspended in TE $(10 \mathrm{mM}$ Tris $/ \mathrm{HCl}, 2 \mathrm{mM}$ EDTA; $\mathrm{pH} 7 \cdot 4$ ). DNA concentration and purity was tested spectrophotometrically at $230,260,280$ and $320 \mathrm{~nm}$ with a GenQuant II spectrophotometer (Pharmacia). DNA base composition was determined by thermal denaturation
(Marmur \& Doty, 1962) under the conditions reported by Raguénès et al. (1997) using DNA from Escherichia coli, Clostridium perfringens and Micrococcus luteus (Sigma) as standards.

$16 S$ rDNA sequence analysis. The $16 \mathrm{~S}$ rDNA was amplified by PCR (Saiki et al., 1988) as described previously (Dauga \& Grimont, 1991), except that an archaea-specific primer was used. The primer sequences were 5'-TCCGGTTGATCCTGCCGGAC-3' (E. coli 16S rRNA gene, positions 2-21) and 5'-CTTTCGGTCGCCCCTACT-3' (Thermococcus celer 23S rRNA, positions 257-234). The PCR product was precipitated and dissolved in $30 \mu \mathrm{l}$ distilled water. The PCR product was cloned into pUC18 by using a SureClone ligation kit (Pharmacia) and also subcloned as HindIIIEcoRI insertions into M13mp18 and M13mpl9 phage vectors. Both strands of one clone were sequenced by the dideoxy chain-termination method (Sanger et al., 1977), except that we used a HotTub DNA sequencing kit (Amersham) to resolve numerous compressions observed during sequencing of genes of hyperthermophilic microorganisms. PCR products were also sequenced directly by using a cycle sequencing kit (type CSDS; Gibco-BRL) and ${ }^{32}$ P-labelled primers (Amersham). As a control, the DNA sequence was also obtained with an automatic DNA analysis system (Applied Biosystems); this work was done at Euro Sequence Gene Service (ESGS, France). A total of 1925 bp was sequenced. The determined sequence was then aligned with available reference $16 \mathrm{~S}$ rRNA sequences. Reference sequences used were: Thermococcus hydrothermalis (Z70244), Thermococcus fumicolans (Z70250), P. furiosus (U20163), 'P. abyssi' (L19921) and 'P. horikoshii' (D87344). The alignment was performed with $1271 \mathrm{bp}$. A multiple sequence file was obtained by using the MEGALIGN program of the DNASTAR package (Promega), similarities and alignment were obtained by the CLUSTAL w method with weighted residues (Thompson et al., 1994) and phylogenetic reconstruction was produced using PHYLO_WIN (Galtier et al., 1996) with the following conditions : distance, Jukes-Cantor, and successively the neighbour-joining (Saitou \& Nei, 1987), maximum-likelihood (Felsenstein, 1981) and maximumparsimony (Lake, 1987) methods. Bootstrap values were determined according to Felsenstein (1985).

Quantitative DNA-DNA hybridization. DNA from the reference strains $P$. furiosus and ' $P$. abyssi' was used as labelled probes in a single hybridization experiment with strain AL585 ${ }^{\mathrm{T}}$. Four to five micrograms of each reference-strain DNA was labelled by incorporation of both $\left[{ }^{3} \mathrm{H}\right] \mathrm{dATP}$ and $\left[{ }^{3} \mathrm{H}\right] \mathrm{dGTP}$ by using a Megaprime kit (Amersham). The nuclease $\mathrm{S} 1$ method for quantitative DNA-DNA hybridization was carried out as described by Popoff \& Coynault (1980) by using DE81 filters (Whatman) and a $\beta$ matic IV scintillation counter (Kontron Instruments).

\section{RESULTS}

\section{Collection of samples}

Chimney walls of active, deep-sea vents, frequently covered with alvinellid communities, were sampled from different sites on the East Pacific Rise at latitudes 11,13 and $21^{\circ} \mathrm{N}$ with the deep-submergence vehicle Alvin during the American oceanographical cruise MVT'90 in 1990. These samples, chimney wall pieces and alvinellid tubes were stored in serum vials filled with sterile sea water under anaerobic conditions obtained by injection of sodium sulfide to a final 

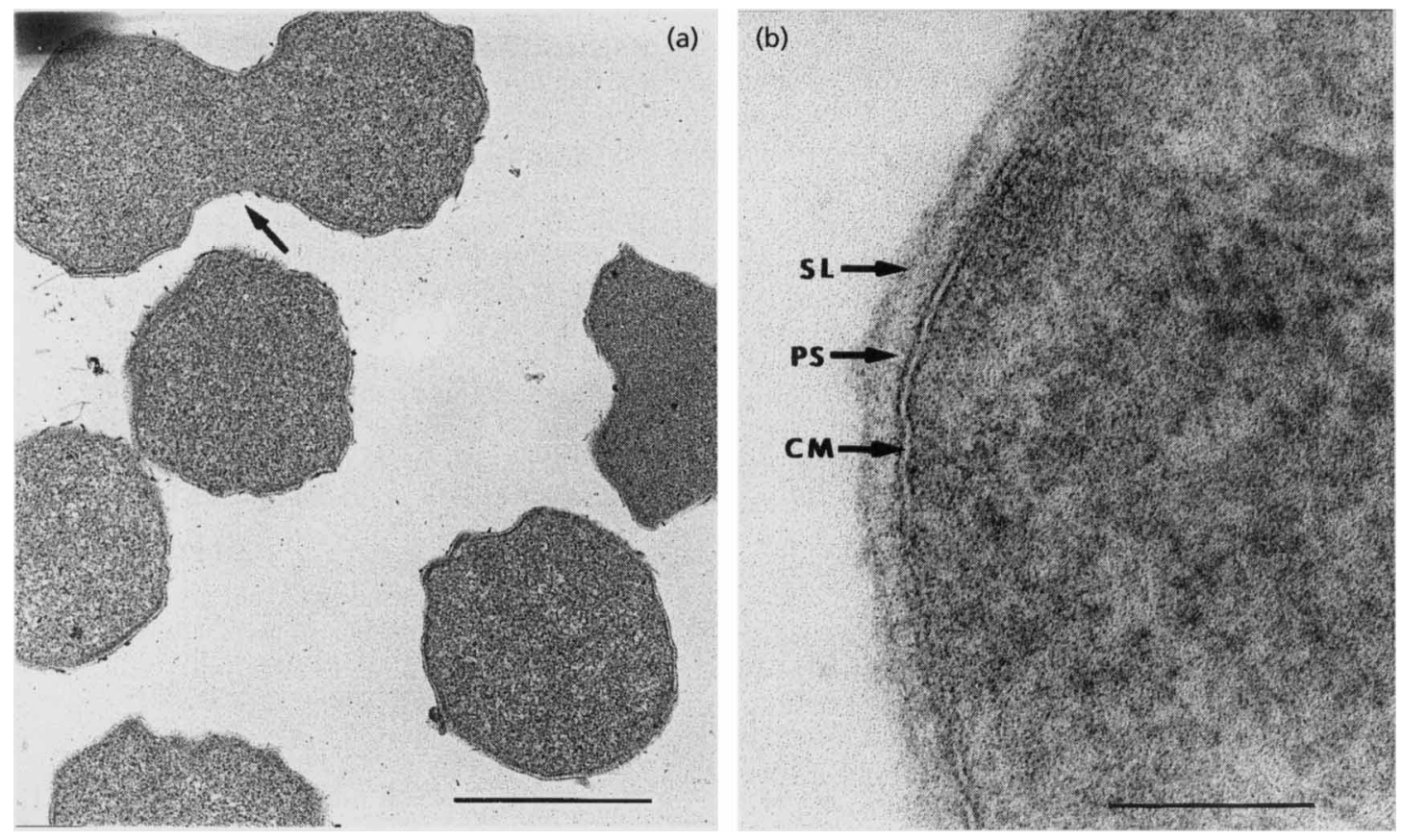

Fig. 1. Transmission electron micrographs of strain $A L 585^{\top}$. (a) Single cells and division by constriction (arrow). Bar, $1 \mu \mathrm{m}$. (b) View of the cell wall. Arrows indicate surface layer (SL), periplasmic space (PS) and cytoplasmic membrane (CM). Bar, $0.1 \mu \mathrm{m}$.

concentration of $0.5 \mathrm{~g}^{-1}$. Samples were brought back to the laboratory at ambient temperature immediately after the cruise. Strain AL585 $5^{\mathrm{T}}$ was isolated from a sample containing pieces of one smoker and its covering of alvinellid tubes collected at a site called Totem, latitude $13^{\circ} \mathrm{N}$, depth $2650 \mathrm{~m}$.

\section{Enrichment and purification}

Strain AL585 $5^{\mathrm{T}}$ was obtained at $95^{\circ} \mathrm{C}$ in BHI-S medium, pH 7.5. Purification of strain AL585 $5^{\mathrm{T}}$ was performed by successive plating of culture samples onto solid BHI-S medium prepared with Gelrite. Small, translucent, colourless colonies appeared within a few days, indicating that growth was slow in such conditions compared with liquid medium. One isolated colony was transferred to liquid medium and stored.

\section{Morphology}

Observations by phase-contrast microscopy revealed that strain AL585 $5^{\mathrm{T}}$ cells were cocci occurring singly, in pairs or in small aggregates. The cells appeared to be motile and polar flagella were observed by phasecontrast microscopy after specific coloration. Numerous diplococci were observed during the exponential growth phase, indicating that cells probably divided by constriction. Under electron microscopy, more or less spherical cocci were observed (Fig. 1a). These cells were delimited by a cytoplasmic membrane $(5 \mathrm{~nm})$ covered by a bilayered cell envelope with an inner periplasmic space $(15 \mathrm{~nm})$ and an external, densely stained layer $(5 \mathrm{~nm})$, probably corresponding to a surface-layer protein as already described for other thermococcales (Huber et al., 1995) (Fig. 1b). Cells divided by constriction, as visible in Fig. 1(a), but budding cells were not observed. Clumps of dense, spherical particles were frequently present inside the cytoplasm and fibres and dense particles were sometimes attached externally to the cell envelope. Electron microscopy permitted the study of the diameter distribution. The diameters of single cells ranged from 0.5 to $1.5 \mu \mathrm{m}$, depending on their size and the axis of measurement. The diameters measured were normally distributed and the mean diameter was $1 \mu \mathrm{m}$.

\section{Growth parameters}

Near atmospheric pressure, strain AL585 ${ }^{\mathrm{T}}$ grew slowly at 75 and $104^{\circ} \mathrm{C}$, but growth was not observed at $107^{\circ} \mathrm{C}$. The maximum growth rate was observed at $95^{\circ} \mathrm{C}$ (Fig. 2a). The highest cell yield was also obtained at this temperature, which can be considered as optimal. Growth was slow at $\mathrm{pH} 2.5$ and 9.5 and the optimum $\mathrm{pH}$ was between 6.5 and 8.5 (Fig. 2 b). The highest cell yield was obtained at $\mathrm{pH} 7 \cdot 5$, which can be considered as the optimum $\mathrm{pH}$. Growth was observed at sea-salt concentrations ranging from 20 to $60 \mathrm{~g} \mathrm{I}^{-1}$. Calculated growth rates were not significantly different between 30,40 and $60 \mathrm{~g} \mathrm{I}^{-1}$. Strain AL585 $5^{\mathrm{T}}$ was unable to grow without sea salt or at a concentration of $80 \mathrm{~g}$ $1^{-1}$ (Fig. 2c). The highest cell concentrations at the end of the exponential phase were obtained for $30 \mathrm{~g}^{-1}$ sea salt, which can be considered as optimal. Under the 

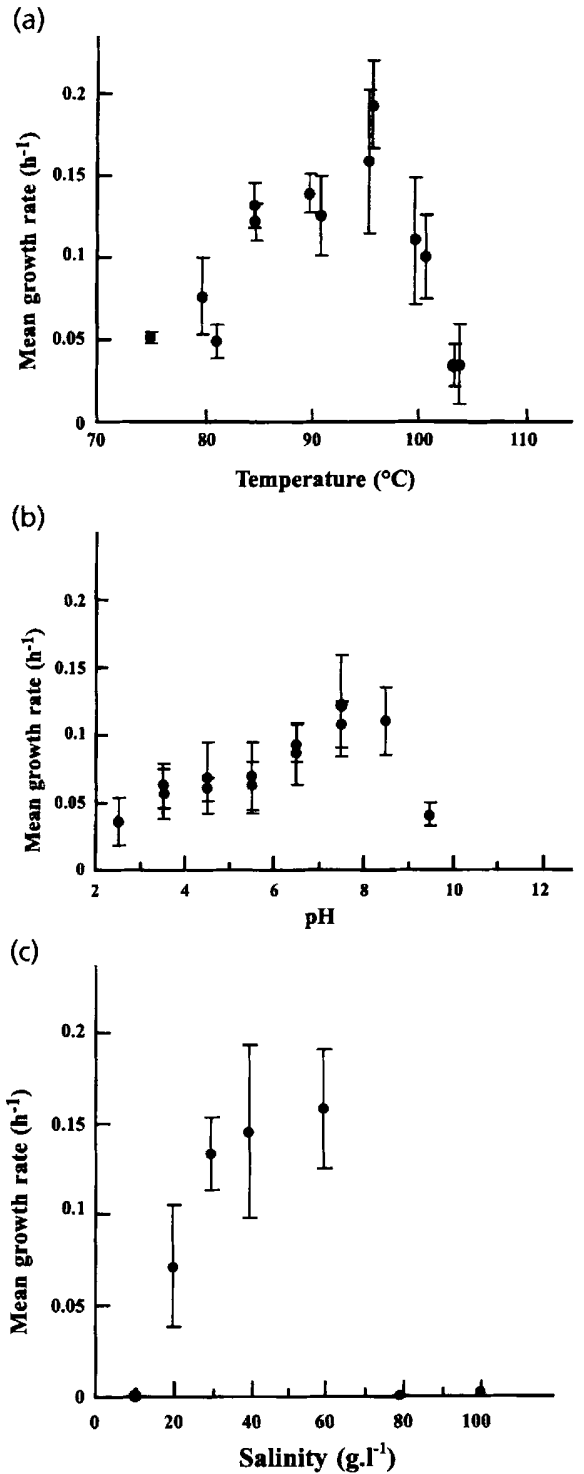

Fig. 2. Temperature, $\mathrm{pH}$ and sea-salt concentration optima for growth of strain AL585 ${ }^{\top}$ on 2216-S medium. (a) Growth rate as a function of temperature ( $30 \mathrm{~g}$ sea salt $\left.\mathrm{I}^{-1}, \mathrm{pH} 7 \cdot 5\right)$. (b) Growth rate as a function of $\mathrm{pH}\left(30 \mathrm{~g}\right.$ sea salt $\left.\mathrm{I}^{-1}, 95^{\circ} \mathrm{C}\right)$. (c) Growth rate as a function of sea-salt concentration $\left(95^{\circ} \mathrm{C}, \mathrm{pH} 7 \cdot 5\right)$. Bars indicate confidence intervals.

supposed optimal conditions $\left(95^{\circ} \mathrm{C}, \mathrm{pH} 7 \cdot 5,30 \mathrm{~g}^{-1}\right.$ sea salt), the mean doubling time from three replicates was 93 min and the highest cell concentration observed was around $5 \times 10^{8}$ cells $\mathrm{ml}^{-1}$. This doubling time was higher than the lowest previously described for other Pyrococcus species: $37 \mathrm{~min}$ for P. furiosus (Fiala \& Stetter, 1986), $35 \mathrm{~min}$ for $P$. woesei (Zillig et al., 1987), 33 min for 'P. abyssi' (Erauso et al., 1993) and $32 \mathrm{~min}$ for 'P. horikoshii' (Gonzalez et al., 1998).

Considering this mean doubling time under optimal conditions, we observed that the duration of cultures made with highly diluted inocula (dilution of $10^{-4} \mathrm{v} / \mathrm{v}$, for instance) until the end of the exponential growth

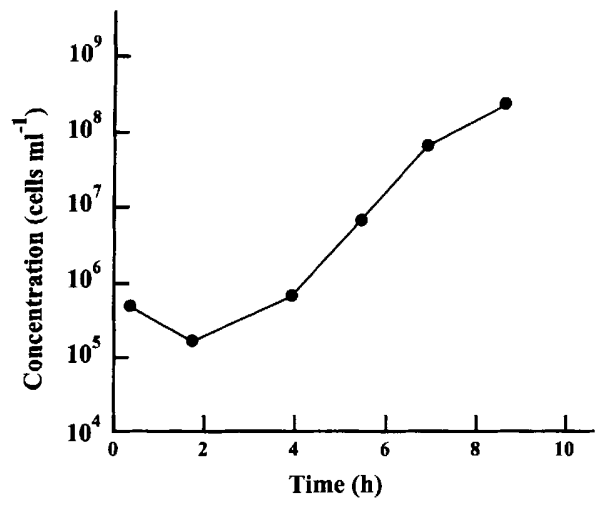

Fig. 3. Growth curve as determined by flow-cytometry counts.

phase was abnormally short. In order to observe the growth kinetics at relatively low concentrations directly, we determined cell numbers against time using flow cytometry. A volume of $0 \cdot 1 \mathrm{ml}$ of a culture containing $2 \times 10^{8}$ cells ml ${ }^{-1}$ was inoculated in $30 \mathrm{ml}$ BHI-S medium and cultivated at $95{ }^{\circ} \mathrm{C}$. This culture was sampled over $8.7 \mathrm{~h}$. Flow cytometry counts are shown in Fig. 3. Three observations were made during the exponential phase of growth and the three corresponding points, from $6 \times 10^{5}$ to $6.2 \times 10^{7}$ cells $\mathrm{ml}^{-1}$, were perfectly aligned $\left(r^{2}=0.9999\right)$. From these points, a doubling time of $27 \mathrm{~min}$ was calculated. These results suggested that growth rates for strain AL $585^{\mathrm{T}}$ calculated at microscopically or densitometrically countable concentrations (from $10^{7}$ to $5 \times 10^{8}$ cells $\mathrm{ml}^{-1}$ ) were suboptimal. This signifies that "optimal growth' (i.e. maximum growth rate) in serum vials or Hungate tubes was only observable at relatively low cell concentrations, not easily compatible with the techniques commonly used for cell counting. When using these techniques, Thoma chamber counts or OD measurements, we observed a transition phase between the exponential growth phase and the stationary phase, during which the growth rate decreased.

\section{Nutritional requirements}

Elemental sulfur clearly stimulated growth of strain AL585 $5^{\mathrm{T}}$ in complex medium (maximum concentrations greater than or equal to $2 \times 10^{8}$ cells $\mathrm{ml}^{-1}$ ) (Fig. 4). We repeatedly observed that cystine had less effect (maximum concentrations between $5 \times 10^{7}$ and $2 \times 10^{8}$ cells $\mathrm{ml}^{-1}$ ) and that polysulfide failed to stimulate growth (maximum concentrations less than or equal to $5 \times 10^{7}$ cells $\mathrm{ml}^{-1}$ ). Elemental sulfur appeared to prolong growth, which was inhibited by metabolic products in its absence. A high concentration $(80 \%)$ of $\mathrm{H}_{2}$ in the gas phase also strongly inhibited growth. In the presence of elemental sulfur, cultures produced large amounts of hydrogen sulfide during growth (data not shown). These results suggest that addition of elemental sulfur prevents $\mathrm{H}_{2}$ inhibition of growth, as proposed by Fiala \& Stetter (1986). 


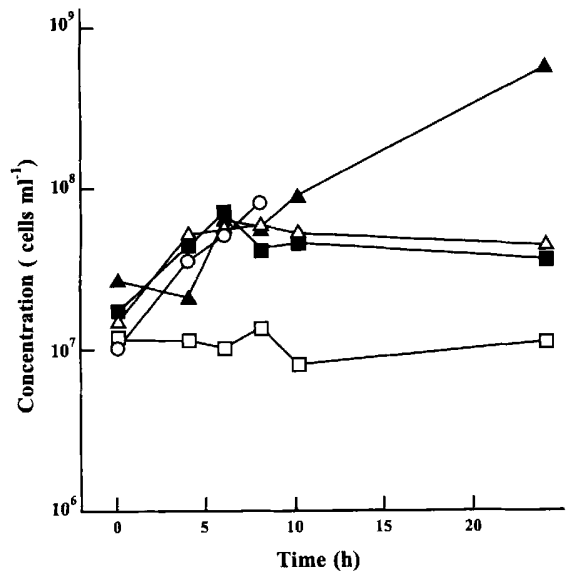

Fig. 4. Influence of the presence and absence of sulfur compounds and of the gas phase on growth of strain $A L 585^{\top}$ in BHI medium. Gas phases tested were $\mathrm{N}_{2} / \mathrm{H}_{2} / \mathrm{CO}_{2}$ (90:5:5), unsupplemented $(\triangle)$ or supplemented with sulfur $(\boldsymbol{\Delta})$, cystine (O) or polysulfide $(\square)$, and $\mathrm{H}_{2} / \mathrm{CO}_{2}(80: 20)(\square)$ (without added sulfur compounds).

Strain $\mathrm{AL} 585^{\mathrm{T}}$ appeared to be an obligate heterotroph. No growth was observed in mineral medium, in the absence of a carbon source, with an $\mathrm{H}_{2} / \mathrm{CO}_{2}$ gas phase $(80: 20)$, with or without elemental sulfur (data not shown). Yeast extract plus peptone (2216-S medium) and brain heart infusion (BHI-S medium) supported rapid and efficient growth of strain $\mathrm{AL} 585^{\mathrm{T}}$ (maximum concentrations greater than or equal to $2 \times 10^{8}$ cells $\mathrm{ml}^{-1}$ ). This strain was also able to grow equally efficiently with peptone or glucose as carbon and energy sources. Less efficient growth was observed with starch and maltose as carbon sources (maximum concentrations between $5 \times 10^{7}$ and $2 \times 10^{8}$ cells $\mathrm{ml}^{-1}$ ). A small amount of growth was obtained with meat extract, yeast extract, chitin, cellobiose and a mixture of 20 amino acids (maximum concentrations between $1.5 \times 10^{7}$ and $5 \times 10^{7}$ cells $\mathrm{ml}^{-1}$ ). None of the other substrates tested as carbon sources permitted growth.

\section{Antibiotic sensitivity}

Strain AL585 ${ }^{\mathrm{T}}$ was resistant to rifampicin, vancomycin, penicillin, kanamycin, streptomycin and chloramphenicol at concentrations of 50,100 and $150 \mu \mathrm{g}$ $\mathrm{ml}^{-1}$. Thermotoga maritima exhibited the expected pattern of antibiotic sensitivity (Huber et al., 1986) at $80^{\circ} \mathrm{C}$, demonstrating that the antibiotics were active at high temperature.

\section{DNA composition}

The $\mathrm{G}+\mathrm{C}$ content of the DNA of strain $\mathrm{AL} 585^{\mathrm{T}}$ was $47 \pm 1 \mathrm{~mol} \%$. The $\mathrm{G}+\mathrm{C}$ contents of $P$. furiosus and ' $P$. abyssi', determined under the same conditions, were $38 \pm 1$ and $44 \pm 1 \mathrm{~mol} \%$. These two values are identical to the values published previously (Fiala \& Stetter, 1986; Erauso et al., 1993).

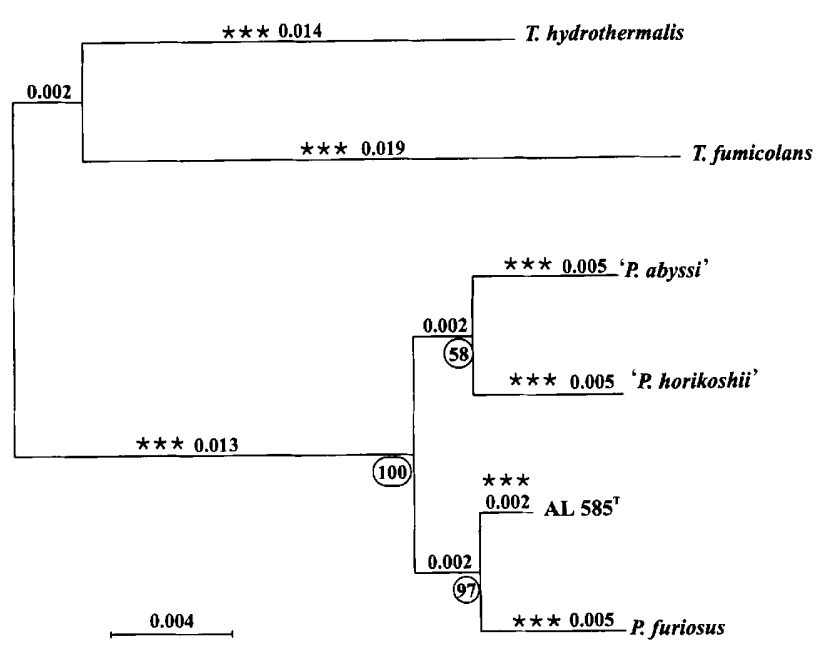

Fig. 5. Unrooted phylogenetic tree of strain $A L 585^{\top}$ and other reference species from the Thermococcales. The tree was based on an alignment done with CLUSTAL $W$ and established using PHYLO-WIN with the following parameters: distance, Jukes-Cantor, and successively neighbour-joining, maximumlikelihood and maximum-parsimony methods. Bootstrap values (encircled numbers) are those of the neighbour-joining method with 500 replicates. $* * *$, All three methods give the same branching. Numbers on the branches give the evolutionary distances.

\section{$16 S$ rRNA sequence analysis}

The sequence of the $16 \mathrm{~S}$ rDNA of strain $\mathrm{AL} 585^{\mathrm{T}}$ was determined and revealed that this isolate belonged to the genus Pyrococcus. Consequently, the sequence was aligned with other available 16S rDNA sequences for Pyrococcus species; sequence similarities were found to be $98 \%$ to $P$.furiosus, ' $P$. abyssi' and 'P. horikoshii', $96 \%$ to Thermococcus hydrothermalis and $94 \%$ to Thermococcus fumicolans. Fig. 5 gives the corresponding phylogenetic tree. In this tree, strain AL585 appeared closer to $P$. furiosus than to ' $P$. abyssi' and 'P. horikoshii'.

\section{DNA-DNA hybridization}

Labelled probes prepared from total DNA from $P$. furiosus and ' $P$. abyssi', the two Pyrococcus species previously described, closely related to strain AL 585 were hybridized with total DNA from strain AL $585^{\mathrm{T}}$. The levels of DNA reassociation measured were 20 and $18 \%$, respectively. We can observe that the values are far below $70 \%$, which is the percentage to consider for definition of a new species (Wayne et al., 1987). Those results confirm that strain $\mathrm{AL} 585^{\mathrm{T}}$ is a new species of Pyrococcus.

\section{DISCUSSION}

The novel marine hyperthermophilic strain AL585 can be assigned to the archaeal domain (Woese et al., 1990) because of its resistance to antibiotics and its $16 \mathrm{~S}$ rDNA sequence. This latter result (Fig. 5) indicates 
Table 1. Comparison of characteristics of strain AL585 ${ }^{\top}$ and other Pyrococcus species

Data were taken from Fiala \& Stetter (1986), Brown et al. (1990), Schäfer \& Schönheit (1991), Kengen et al. (1993) and Raven \& Sharp (1997) (P. furiosus); Zillig et al. (1987), Koch et al. (1991) and Rüdiger et al. $(1992,1995)$ (P. woesei); Erauso et al. (1993) ('P. abyssi'); and Gonzalez et al. (1998) ('P. horikoshii'). ND, Not determined.

\begin{tabular}{|c|c|c|c|c|c|}
\hline Characteristic & $\begin{array}{l}\text { P. furiosus } V \mathrm{cl}^{\mathrm{T}} \\
\left(=\mathrm{DSM} 3638^{\mathrm{T}}\right)\end{array}$ & P. woesei DSM $3773^{\mathrm{T}}$ & $\begin{array}{c}\text { 'P.abyssi' GE5 } \\
(=\text { CNCM 1-1302) }\end{array}$ & 'P. horikoshii' JCM 9974 & Strain AL585 ${ }^{\top}$ \\
\hline $\mathrm{G}+\mathrm{C}$ content $(\mathrm{mol} \%)$ & $37-38$ & $37 \cdot 5$ & $44-45$ & 44 & 47 \\
\hline \multicolumn{6}{|l|}{ Growth temperature $\left({ }^{\circ} \mathrm{C}\right)$ : } \\
\hline Optimum & 100 & $100-103$ & 96 & 98 & 95 \\
\hline Range & $70-103$ & Up to $105^{*}$ & $67-102$ & $80-102$ & $75-104$ \\
\hline \multicolumn{6}{|l|}{$\mathrm{pH}:$} \\
\hline Optimum & 7 & ND & $6 \cdot 8$ & $7-0$ & $7 \cdot 5$ \\
\hline Range & $5-9$ & ND & $4 \cdot 0-8 \cdot 5$ & $5-8$ & $2 \cdot 5-9 \cdot 5$ \\
\hline \multicolumn{6}{|c|}{$\mathrm{NaCl}$ concentration $\left(\mathrm{g} \mathrm{l}^{-1}\right)$ : } \\
\hline Optimum & 20 & 30 & 30 & 24 & 26 \\
\hline Range & $5-50$ & ND & $7-50$ & $10-50$ & $17-52$ \\
\hline Carbon sources used & $\begin{array}{l}\text { Yeast extract, peptone, } \\
\text { tryptone, meat extract, } \\
\text { casein, starch, maltose, } \\
\text { cellobiose, glycogen, } \\
\text { pullulan, pyruvate }\end{array}$ & $\begin{array}{l}\text { Yeast extract, tryptone, } \\
\text { glycogen, starch, gellan }\end{array}$ & $\begin{array}{l}\text { Brain heart infusion, yeast } \\
\text { extract, meat extract, } \\
\text { peptone, tryptone, } 20 \\
\text { amino acids }\end{array}$ & $\begin{array}{l}\text { Peptone, yeast extract, beef } \\
\text { extract, tryptone, casein, } \\
20 \text { amino acids }\end{array}$ & $\begin{array}{l}\text { Brain heart infusion, yeast } \\
\text { extract, peptone, meat } \\
\text { extract, starch, chitin, } \\
\text { maltose, cellobiose, } \\
\text { glucose, } 20 \text { amino acids }\end{array}$ \\
\hline
\end{tabular}

* No minimum temperature for growth was given.

that this strain belongs to the order Thermococcales (Zillig et al., 1987), which is so far represented by two genera, Pyrococcus (Fiala \& Stetter, 1986) and Thermococcus (Zillig et al., 1983), and the strain is included in the genus Pyrococcus. The new strain has a morphology similar to the previously described species of Pyrococcus and, similar to other strains of Pyrococcus, strain $\mathrm{AL} 585^{\mathrm{T}}$ has an optimal growth temperature above $90^{\circ} \mathrm{C}$, while Thermococcus species grow optimally below $90^{\circ} \mathrm{C}$ (Godfroy et al., 1996, 1997; Miroshnichenko et al., 1998; Canganella et al., 1998; Duffaud et al., 1998). Characteristics of strain AL585 $5^{\mathrm{T}}$ and other species of the genus Pyrococcus are shown in Table 1. Strain AL585 $5^{\mathrm{T}}$ has a G $+\mathrm{C}$ content higher than other strains of Pyrococcus, and this criterion distinguishes the abyssal strains ('P. abyssi', ' $P$. horikoshii' and strain AL585 ${ }^{\mathrm{T}}$ ) very clearly from the coastal strains ( $P$. furiosus and $P$. woesei). However, the growth responses to temperature, $\mathrm{pH}$ and salinity do not differentiate strain AL585 ${ }^{\mathrm{T}}$ from the other species of Pyrococcus. The maximum growth rate observed for strain AL585 $5^{\mathrm{T}}$ corresponds to a doubling time of $0.5 \mathrm{~h}$, which is similar to that observed for other Pyrococcus species. However, in the case of strain AL585 ${ }^{\mathrm{T}}$, the maximum growth rate was much lower (doubling time of $1.5 \mathrm{~h}$ ) at the end of the exponential phase of growth, in the range of cell concentrations usually studied. We can hypothesize that this transition phase could reveal the existence of a limiting factor for growth or an inhibiting effect of metabolic products when growth occurs in closed vessels. This last hypothesis will have to be tested further by studying the behaviour of strain AL585 when grown in a fermenter.

As with other Pyrococcus species, strain AL585 ${ }^{\mathrm{T}}$ grows efficiently in the presence of proteinaceous substrates. Unlike ' $P$. abyssi' and ' $P$. horikoshii', strain AL $585^{\mathrm{T}}$ is also able to use different carbohydrates, an ability already described for $P$. furiosus and $P$. woesei. This is in line with 16S rDNA sequence comparisons (Fig. 5), which separated Pyrococcus species in two groups corresponding with these phenotypic differences. However, strain AL585 is able to use glucose as a carbon source for its growth, a feature that appears to be unique in the genus Pyrococcus. This ability to ferment proteins, amino acids and carbohydrates in the presence of sulfur appears to correspond to the characteristics of the original ecosystem surrounding this isolate. Strain AL585 was isolated from pieces of an active smoker covered with an alvinellid colony, made mainly of Alvinella pompejana individuals. Current knowledge of the ecology of this species (Desbruyères et al., 1998) clearly indicates that all the major elements we used to prepare culture media (sea salt, sulfur, proteins and carbohydrates) are present in the immediate vicinity of this animal.

On the basis of its physiological characteristics, its $16 \mathrm{~S}$ rDNA sequence and DNA-DNA hybridization data, strain AL585 ${ }^{\mathrm{T}}$ represents an new species of Pyrococcus, and we propose to name it Pyrococcus glycovorans sp. nov.

\section{Description of Pyrococcus glycovorans Barbier, Godfroy, Meunier and Raguénès sp. nov.}

Pyrococcus glycovorans (gly.co.vo'rans. Gr. adj.glykos sweet, referring to glucose; L. part. pres. vorans eating, devouring; M.L. part. adj. glycovorans eating glucose).

Cells are cocci with a mean diameter of $1 \mu \mathrm{m}$ (range $0 \cdot 5-1.5 \mu \mathrm{m}$ ), motile with polar flagella. Cell division occurs by constriction. Obligately anaerobic. Grows optimally at $30 \mathrm{~g} \mathrm{l}^{-1}$ sea salt and $\mathrm{pH} 7.5$. At atmospheric pressure, growth occurs between 75 and $104^{\circ} \mathrm{C}$. Obligately chemo-organotrophic. Ferments protein 
and proteolytic products and carbohydrates, especially glucose. Sulfur is not necessary for growth but significantly enhances final cell concentrations when grown in closed culture vessels. Sulfur is reduced to $\mathrm{H}_{2} \mathrm{~S}$. At low cell concentrations, under optimal conditions and at atmospheric pressure, doubling time is $0.5 \mathrm{~h}$ and maximal concentrations at the beginning of the stationary phase can reach $5 \times 10^{8}$ cells $\mathrm{ml}^{-1}$. G+C content is $47 \mathrm{~mol} \%$. 16S rDNA sequence comparisons locate Pyrococcus glycovorans within the Thermococcales, in the archeal domain. The GenBank/EMBL accession number for the $16 \mathrm{~S}$ rDNA sequence is Z70247.

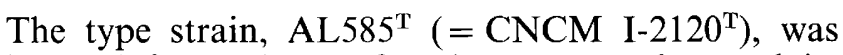
isolated from pieces of a deep-sea smoker and its covering of alvinellid tubes collected at $13^{\circ} \mathrm{N}$ at a depth of $2650 \mathrm{~m}$ on the East Pacific Rise.

\section{ACKNOWLEDGEMENTS}

We thank the chief scientists of the American oceanographical cruise MVT'90, Richard A. Lutz and Robert Vriejenhoek (Institute of Marine and Coastal Sciences, Rutgers University, New Brunswick, NJ, USA) and our colleagues Anne-Marie Alayse and Daniel Desbruyères (IFREMER, Centre de Brest, France) for collection of samples. We thank the captain and crew of N.O. Atlantis II and the D.S.V.Alvin pilots and support crew. We also thank Dominique Marie (CNRS, Station Biologique, Roscoff, France) and Germaine Dorange (Université de Bretagne Occidentale, UFR Sciences, Brest, France) for their technical support, respectively for flow cytometric analysis and transmission electron microscopy. We thank Pascale Fritayre, Aline Blanchet and Audrey Roux, who helped technically during their training periods at IFREMER. This work was supported by IFREMER, the French Research Ministry and Région Bretagne.

\section{REFERENCES}

Balch, W. E., Fox, G. E., Magrum, L. J., Woese, C. R. \& Wolfe, R. S. (1979). Methanogens: reevaluation of a unique biological group. Microbiol Rev 43, 260-296.

Belkin, S. \& Jannasch, H. W. (1985). A new extremely thermophilic, sulfur-reducing heterotrophic, marine bacterium. Arch Microbiol 141, 181-186.

Blöchl, E., Burggraf, S., Fiala, G. \& 7 other authors (1995). Isolation, taxonomy and phylogeny of hyperthermophilic microorganisms. World J Microbiol \& Biotechnol 11, 9-16.

Blumentals, I. I., Itoh, M., Olson, G. J. \& Kelly, R. M. (1990). Role of polysulfides in reduction of elemental sulfur by the hyperthermophilic archacbacterium Pyrococcus furiosus. Appl Environ Microbiol 56, 1255-1262.

Brock, T. D. (1992). Research on thermophiles. In Thermophiles: Science and Technology, pp. A3-A12. Reykjavik: Icetec.

Brown, S. H., Costantino, H. R. \& Kelly, R. M. (1990). Characterization of amylolytic enzyme activities associated with the hyperthermophilic archaebacterium Pyrococcus furiosus. Appl Environ Microbiol 56, 1985-1991.

Canganella, F., Jones, W. J., Gambacorta, A. \& Antranikian, G. (1998). Thermococcus guaymasensis sp. nov. and Thermococcus aggregans sp. nov., two novel thermophilic archaea isolated from the Guaymas Basin hydrothermal vent site. Int $J$ Syst Bacteriol 48, 1181-1185.

Dauga, P. A. D. \& Grimont, P. A. D. (1991). Nucleotide sequence of 16S rRNA from ten Serratia species. Res Microbiol 141, 1139-1149.

Desbruyères, D., Chevaldonné, P., Alayse, A.-M. \& 15 other authors (1998). Biology and ecology of the 'Pompeii worm' (Alvinella pompejana Desbruyères and Laubier), a normal dweller of an extreme deep-sea environment: a synthesis of current knowledge and recent developments. Deep-Sea Res Part II Top Stud Oceanogr 45, 383-422.

Duffaud, G. D., d'Hennezel, O. B., Peek, A. S., Reysenbach, A.-L. \& Kelly, R. M. (1998). Isolation and characterization of Thermococcus barossii, sp. nov., a hyperthermophilic archaeon isolated from a hydrothermal vent flange formation. Syst Appl Microbiol 21, 40-49.

Erauso, G., Reysenbach, A. L., Godfroy, A. \& 8 other authors (1993). Pyrococcus abyssi sp. nov., a new hyperthermophilic archaeon isolated from a deep-sea hydrothermal vent. Arch Microbiol 160, 338-349.

Felsenstein, J. (1981). Evolutionary trees from DNA sequences: a maximum likelihood approach. $J$ Mol Evol 17, 368-376.

Felsenstein, J. (1985). Confidence limits on phylogenies: an approach using the bootstrap. Evolution 30, 783-791.

Fiala, G. \& Stetter, K. O. (1986). Pyrococcus furiosus sp. nov. represents a novel genus of marine heterotrophic archaebacteria growing optimally at $100^{\circ} \mathrm{C}$. Arch Microbiol 145, 56-61.

Galtier, N., Gouy, M. \& Gautier, C. (1996). SEAVIEW and PHYLOWIN: two graphic tools for sequence alignment and molecular phylogeny. Comput Appl Biosci 12, 543-548.

Godfroy, A., Meunier, J.-R., Guezennec, J., Lesongeur, F., Raguénès, G., Rimbault, A. \& Barbier, G. (1996). Thermococcus fumicolans sp. nov., a new hyperthermophilic archaeon isolated from a deep-sea hydrothermal vent in the North Fiji Basin. Int $J$ Syst Bacteriol 46, 1113-1119.

Godfroy, A., Lesongeur, F., Raguénès, G., Quérellou, J., Antoine, E., Meunier, J.-R., Guezennec, J. \& Barbier, G. (1997). Thermococcus hydrothermalis sp. nov., a new hyperthermophilic archaeon isolated from a deep-sea hydrothermal vent. Int $J$ Syst Bacteriol 47, 622-626.

Gonzalez, J. M., Masuchi, Y., Robb, F. T., Ammerman, J. W. Maeder, D. L., Yanagibayashi, M., Tamaoka, J. \& Kato, C. (1998). Pyrococcus horikoshii sp. nov., a hyperthermophilic archaeon isolated from a hydrothermal vent at the Okinawa Trough. Extremophiles 2, 123-130.

Hobbie, J. E., Daley, R. J. \& Jasper, S. (1977). Use of nuclepore filters for counting bacteria by fluorescence microscopy. Appl Environ Microbiol 33, 1225-1228.

Huber, R., Langworthy, T. A., König, H., Thomm, M., Woese, C. R., Sleytr, U. B. \& Stetter, K. O. (1986). Thermotoga maritima sp. nov, represents a new genus of unique extremely thermophilic eubacteria growing up to $90^{\circ} \mathrm{C}$. Arch Microbiol 144, 324-333.

Huber, R., Stöhr, J., Hohenhaus, S., Rachel, R., Burggraf, S., Jannasch, H. W. \& Stetter, K. O. (1995). Thermococcus chitonophagus sp. nov., a novel, chitin-degrading, hyperthermophilic archaeum from a deep-sea hydrothermal vent environment. Arch Microbiol 164, 255-264.

Kengen, S. W. M., Luesink, E. J., Stams, A. J. M. \& Zehnder, A. J. B. (1993). Purification and characterization of an extremely thermostable $\beta$-glucosidase from the hyperthermophilic archaeon Pyrococcus furiosus. Eur J Biochem 213, 305-312. 
Koch, R., Spreinat, A., Lemke, K. \& Antranikian, G. (1991). Purification and properties of a hyperthermoactive $\alpha$-amylase from the archaeobacterium Pyrococcus woesei. Arch Microbiol 155, 572-578.

Lake, J. A. (1987). A rate-independent technique for analysis of nucleic acid sequences: evolutionary parsimony. Mol Biol Evol 4, 167-191.

Leuschner, C. \& Antranikian, G. (1995). Heat-stable enzymes from extremely thermophilic and hyperthermophilic microorganisms. World J Microbiol \& Biotechnol 11, 95-114.

Marmur, J. \& Doty, P. (1962). Determination of the base composition of desoxyribonucleic acid from its thermal denaturation temperature. $J \mathrm{Mol}$ Biol 5, 109-118.

Miroshnichenko, M. L., Gongadze, G. M., Rainey, F. A., Kostyukova, A. S., Lysenko, A. M., Chernyh, N. A. \& BonchOsmolovskaya, E. A. (1998). Thermococcus gorgonarius sp. nov. and Thermococcus pacificus $\mathrm{sp}$. nov.: heterotrophic extremely thermophilic archaea from New Zealand submarine hot vents. Int J Syst Bacteriol 48, 23-29.

Moensch, T. T. \& Zeikus, J. G. (1983). An improved preparation method for a titanium(III) media reductant. $J$ Microbiol Methods 1, 199-202.

Popoff, M. Y. \& Coynault, C. (1980). Use of DEAE-cellulose filters in the S1 nuclease method for bacterial deoxyribonucleic acid hybridization. Ann Microbiol (Paris) 131A, 151-155.

Porter, K. G. \& Feig, Y. S. (1980). The use of DAPI for identifying and counting microflora. Limnol Oceanogr 25, 943-948.

Raguénès, G., Meunier, J.-R., Antoine, E., Godfroy, A., Caprais, J.-C., Lesongeur, F., Guézennec, J. \& Barbier, G. (1995). Biodiversité d'archaea hyperthermophiles des sites hydrothermaux du Pacifique oriental. C R Acad Sci Ser III Sci Vie 318, 395-402.

Raguénès, G., Christen, R., Guézennec, J., Pignet, P. \& Barbier, G. (1997). Vibrio diabolicus sp. nov., a new polysaccharide-secreting organism isolated from a deep-sea hydrothermal vent polychaete annelid, Alvinella pompejana. Int $J$ Syst Bacteriol 47, 989-995.

Raven, N. D. H. \& Sharp, R. J. (1996). Development of defined and minimal media for the growth of the hyperthermophilic archaeon Pyrococcus furiosus Vcl. FEMS Microbiol Lett 146, 135-141.

Rüdiger, A., Ogbonna, J. C., Märkl, H. \& Antranikian, G. (1992). Effect of gassing, agitation, substrate supplementation and dialysis on the growth of an extremely thermophilic archaeon Pyrococcus woesei. Appl Microbiol Biotechnol 37, 501-504.

Rüdiger, A., Jorgensen, P. L. \& Antranikian, G. (1995). Isolation and characterization of a heat-stable pullulanase from the hyperthermophilic archaeon Pyrococcus woesei after cloning and expression of its gene in Escherichia coli. Appl Environ Microbiol 61, 567-575.

Saiki, R. K., Gelfand, D. H., Stoffel, S., Scharf, S. J., Higuchi, R., Horn, G. T., Mullis, K. B. \& Erlich, H. A. (1988). Primer-directed enzymatic amplification of DNA with a thermostable DNA polymerase. Science 239, 487-491.

Saitou, M. \& Nei, M. (1987). The neighbor-joining method: a new method for reconstructing phylogenetic trees. Mol Biol Evol 4 , 406-425.

Sanger, F., Nicklen, S. \& Coulson, A. R. (1977). DNA sequencing with chain-terminating inhibitors. Proc Natl Acad Sci USA 74, 5463-5467.

Schäfer, T. \& Schönheit, P. (1991). Pyruvate metabolism of the hyperthermophilic archaebacterium Pyrococcus furiosus. Arch Microbiol 155, 366-377.

Thompson, J. D., Higgins, D. G. \& Gibson, T. J. (1994). CLUSTAL $\mathrm{W}$ : improving the sensitivity of progressive multiple sequence alignment through sequence weighting, position-specific gap penalties and weight matrix choice. Nucleic Acids Res 22 , 4673-4680.

Wayne, L. G., Brenner, D. J., Colwell, R. R. \& 9 other authors (1987). Report of the ad hoc committee on reconciliation of approaches to bacterial systematics. Int $J$ Syst Bacteriol 37, 463-464.

Woese, C. R., Kandler, O. \& Wheelis, M. L. (1990). Towards a natural system of organisms: proposal for the domains Archaea, Bacteria, and Eucarya. Proc Natl Acad Sci USA 87, 4576-4579.

Zillig, W., Holz, I., Janekovik, D., Schäfer, W. \& Reiter, W. D. (1983). The archaebacterium Thermococcus celer represents a novel genus within the thermophilic branch of the archaebacteria. Syst Appl Microbiol 4, 88-94.

Zillig, W., Holz, I., Klenk, H.-P., Trent, J., Wunderl, S., Janekovic, D., Imsel, E. \& Haas, B. (1987). Pyrococcus woesei, sp. nov., an ultra-thermophilic marine Archaebacterium, representing a novel order, Thermococcales. Syst Appl Microbiol 9, 62-70. 